\title{
Use of technology for self-care in surgical wound infection surveillance: integrative review
}

\author{
Uso de tecnologia para o autocuidado na vigilância de infecção da ferida cirúrgica: revisão integrativa
}

Uso de tecnología para el autocuidado en la vigilancia de infección de la herida quirúrgica: revisión integradora

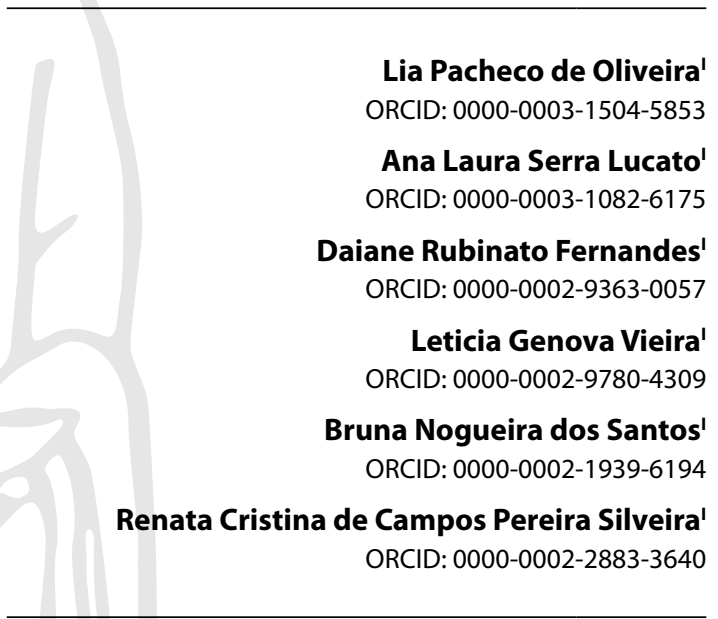

'Universidade de São Paulo. Ribeirão Preto, São Paulo, Brazil.

How to cite this article:

Oliveira LP, Lucato ALS, Fernandes DR, Vieira LG, Santos BN Silveira RCCP. Use of technology for self-care in surgical wound infection surveillance: integrative review.

Rev Bras Enferm. 2022;75(3):e20210208. https://doi.org/10.1590/0034-7167-2021-0208

Corresponding author:

Renata Cristina de Campos Pereira Silveira E-mail: recris@eerp.usp.br

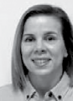

EDITOR IN CHIEF: Antonio José de Almeida Filho ASSOCIATE EDITOR: Alexandre Balsanell

Submission: $04-26-2021$

Approval: 08-16-2021

\section{ABSTRACT}

Objectives: to synthesize knowledge about technology for self-care in surgical wound infection surveillance. Methods: integrative review conducted in CINAHL, Embase, LILACS, PubMed, Scopus and Web of Science databases with the descriptors "surgical wound infection" and "self-care", in addition to manual search in the references of the included studies. The selection and evaluation of the methodological quality of the studies and data collection were performed by two independent reviewers; conflicts were resolved by a third reviewer. Results: nine primary studies were included, published between 2011 and 2019. Six are cross-sectional, two are randomized clinical trials, and one is a case report. Mobile, text messaging, and imaging applications, computer software, assessments, and data storage capacity stand out. Conclusions: the technologies identified for self-care in surgical wound infection surveillance were the creation and use of mHealth and the use of health apps on mobile devices. Effective technologies in surveillance of surgical wound infection that enable rapprochement with the healthcare team, encourage a greater number of surgical wound assessments, enhance self-care actions, and decrease patient anxiety. Technology is also a monitored and recorded form of patient care, one of the main axes of infection surveillance. Descriptors: Self Care; Surgical Wound; Public Health Surveillance; Surgical Wound Infection; Technology.

\section{RESUMO}

Objetivos: sintetizar o conhecimento sobre tecnologia para o autocuidado na vigilância de infecção da ferida cirúrgica. Métodos: revisão integrativa realizada nas bases de dados CINAHL, Embase, LILACS, PubMed, Scopus e Web of Science com os descritores "surgical wound infection" e"selfcare", além da busca manual nas referências dos estudos incluídos. A seleção e avaliação da qualidade metodológica dos estudos e coleta de dados foram realizadas por dois revisores independentes; e os conflitos, resolvidos por um terceiro revisor. Resultados: nove estudos primários foram incluídos, publicados entre 2011 e 2019. Seis são de delineamento transversal, dois ensaios clínicos randomizados e um relato de caso. Destacam-se os aplicativos mobile, de mensagens de texto e de imagens, softwares para computadores, avaliações e capacidade de armazenamento de dados. Conclusões: as tecnologias identificadas para o autocuidado na vigilância de infecção da ferida operatória foram a criação e utilização de mHealth e o uso de aplicativos de saúde em dispositivos móveis. Tecnologias eficazes na vigilância da infecção da ferida operatória que permitem aproximação com a equipe de saúde incentivam um maior número de avaliações da ferida operatória, intensificam as ações de autocuidado e diminuem a ansiedade do paciente. A tecnologia também é uma forma monitorizada e registrada de atendimento ao paciente, um dos principais eixos da vigilância de infecção.

Descritores: Autocuidado; Ferida Cirúrgica; Vigilância em Saúde Pública; Infecção da Ferida Cirúrgica; Tecnologia.

\section{RESUMEN}

Objetivos: sintetizar el conocimiento sobre tecnología para el autocuidado en la vigilancia de infección de la herida quirúrgica. Métodos: revisión integradora realizada en las bases de datos CINAHL, Embase, LILACS, PubMed, Scopus y Web of Science con los descriptores "surgical wound infection" $y$ "self care", además de búsqueda manual en referencias de estudios incluidos. La selección y evaluación de la calidad metodológica de estudios y recolecta de datos fueron realizadas por dos revisores independientes; $y$ los conflictos, por un tercero. Resultados: nueve estudios primarios fueron incluidos, publicados entre 2011 y 2019. Seis son de delineamento transversal, dos ensayos clínicos randomizados y un relato de caso. Destacados los aplicativos mobile, de mensajes de texto y de imágenes, softwares para ordenadores, evaluaciones y capacidad de almacenamiento de datos. Conclusiones: las tecnologías identificadas para el autocuidado en la vigilancia de infección de la herida quirúrgica fueron la creación y utilización de mHealth y uso de aplicativos de salud en dispositivos móviles. Tecnologías eficaces en la vigilancia de la infección de la herida quirúrgica que permiten acercamiento con el equipo de salud, incentivan un mayor número de evaluaciones de la herida quirúrgica, intensifican las acciones de autocuidado y disminuyen la ansiedad del paciente. La tecnología también es una manera monitorizada y registrada de atención al paciente, uno de los principales ejes de la vigilancia de infección. Descriptores: Autocuidado; Herida Quirúrgica; Vigilancia en Salud Pública; Infección de la Herida Quirúrgica; Tecnología. 


\section{INTRODUCTION}

Surgical site infections (SSI) are infections resulting from a surgical procedure and represent one of the main types of health care-related infection in Brazil, with an incidence in general and specific surgeries ranging from $1.4 \%$ to $38.8 \%^{(1)}$. The diagnosis can be made between 30 days and one year after the procedure, depending on some criteria, such as the type of procedure, the presence or not of implants, among others ${ }^{(2)}$.

SSI are classified according to the planes affected: superficial incisional SSI, deep incisional SSI, and organ/cavity SSI. Superficial incisional SSI involves the skin and subcutaneous tissue, occurs within 30 days after the procedure, and the patient presents purulent drainage; isolation of microorganism in culture of secretion or tissue from the superficial incision, or signs and symptoms such as pain, heat, redness, localized swelling and hyperemia ${ }^{(3)}$.

Deep incisional SSI involves the fascia and muscles and can occur within 30 days or up to a year after surgery, depending on whether or not implants are placed. The patient presents purulent drainage; incision dehiscence; fever higher than $38^{\circ} \mathrm{C}$, localized pain or swelling; or deep tissue infection evidenced by clinical, radiological, histopathological, or reoperation examination ${ }^{(3)}$.

Organ/cavity SSI (SSI/OC) refers to any part of the body excluding the skin, fascia and muscles manipulated in the surgical procedure. It occurs within one year after implant placement and has the presence of purulent discharge from a deep drain; fever, hyperemia, pain, heat, or chills; microorganism isolated in fluid or tissue culture; deep tissue infection evidenced by clinical, laboratory, radiological, histopathological, or reoperation examinatio ${ }^{(3)}$.

Knowledge of the clinical manifestations of a SSI is essential for early detection of this complication in the postoperative period. During hospitalization, health professionals are primarily responsible for this surveillance and diagnosis, but such monitoring should be continued in the post-discharge period through patient self-care action ${ }^{(3)}$.

One of the axes of the National Plan for Patient Safety of the National Health Surveillance Agency is the involvement of citizens in their safety. This axis is defined by the autonomy and protagonism of the subjects and suggests that patient safety is improved if they are protagonists of their own care, with autonomy to claim their rights, question, discuss their diagnosis and treatment with health professionals, participating as partners of these $\mathrm{e}^{(4)}$.

In this way, involving the patient in all the links of care leads to their appreciation and turns them into a health promoter. Through educational processes, the patient becomes capable of developing skills and attitudes about their own health, influencing the expected results and making the processes more effective ${ }^{(5)}$.

Currently, the use of technology emerges as an innovative solution for health care, facilitating communication between patients and professionals involved at all levels of care ${ }^{(6-7)}$. The use of applications in mobile devices has been widely discussed as an efficient tool to help and involve patients and family members in self-care, bringing them closer to the professionals, facilitating communication between them and reducing post-discharge anxiety ${ }^{(8-9)}$. The increase in the use of smartphones by the population proves the progress in access to information systems and clinical tools and adherence to the use of technologies ${ }^{(6)}$.

The English term "mobile health" (mHealth) is widely used to refer to health-related mobile device applications. Its key benefits include the provision of personalized health advice, the possibility of remote consultation with health professionals, and, in surgical cases, the assessment and measurement of the surgical wound, and the provision of the specific advice required, such as the choice of dressing cover ${ }^{(9)}$.

The mHealth application offers benefits to patients and health professionals by transforming the exchange and storage of information, providing an individualized approach to each patient and family member, with the goal of empowering them for self-care and strengthening self-management of their medical condition ${ }^{(9)}$.

Considering the importance of the inclusion of patients in their own care and the ease and proximity guaranteed by the use of technological tools, the present review proposes to synthesize the knowledge on the use of technologies for self-care of the surgical wound in surgical site infection surveillance.

\section{OBJECTIVES}

To synthesize knowledge about the use of technology for selfcare of the surgical wound, in surgical site infection surveillance.

\section{METHODS}

\section{Ethical aspects}

Since this is a secondary study, it does not require approval from the Research Ethics Committee (REC). There were no conflicts of interest that could compromise the analysis of the results of this study.

\section{Study design, time and place}

This study consists of an integrative literature review (as proposed by Mendes, Silveira and Galvão( ${ }^{(10)}$ ), which makes it possible to gather and synthesize the production of knowledge, ensuring a theoretical deepening from different perspectives on the same theme. Six steps were followed: identification of the theme, sampling, categorization of studies, evaluation of included studies, interpretation of results, and synthesis of knowledge. The PRISMA Flowchart (Preferred Reporting Items for Systematic Reviews and Meta-Analyzes) was used as a reference to conduct the research and report the results ${ }^{(11)}$. The search of the electronic databases was conducted on June 29,2020 , with no restriction on publication period.

\section{Inclusion and exclusion criteria}

Primary studies, published in Portuguese, English and Spanish, which addressed technologies for self-care of adult patients undergoing elective surgery with surgical wound approximation by first intention were included. Primary studies with children, secondary studies, editorials, letters to the reader, doctoral theses, master's dissertations and abstracts of conference proceedings were excluded. 


\section{Study protocol}

\section{Guiding question}

The question of the present integrative review was: "What is the available evidence on the use of technology for self-care in surgical site infection surveillance?" It was developed based on the PICO strategy ${ }^{(12)}$, where: $\mathrm{P}$ - adult patients undergoing surgical procedure; I - use of technologies for self-care of the surgical wound; $\mathrm{C}$ - not applicable; and $\mathrm{O}$ - surveillance of surgical site infection.

To identify the studies, the electronic databases CINAHL, Embase, LILACS, PubMed, Scopus and Web of Science were used. The search strategy was formulated according to the specificities of each database, using the following controlled descriptors and/ or keywords associated with Boolean operators AND and OR: "surgical wound infection", "surgical site infection", "postoperative wound infection", "wound infection", "surgical wound", "incision care", and "self-care". The search strategies used in each database are shown in Chart 1.

After searching the databases, the results were exported to the online version of the EndNote Basic ${ }^{(13)}$ reference manager to remove duplicate references. Then, they were imported into the online platform Rayyan (Qatar Computing Research Institute), accessed through the e-mail address https://rayyan.qcri.org ${ }^{(14)}$.

On the Rayyan platform, the studies were first assessed by title and abstract by two reviewers (L.P.O. and D.R.F.) independently to verify that the articles met the eligibility criteria. Studies eligible at this stage were selected to be read in their entirety, and in case of disagreement between reviewers, a third reviewer (A.L.S.L.) with expertise in the subject was consulted.

\section{Categorization of studies}

The data from the studies were collected using an instrument adapted from Silveira et al. ${ }^{(15)}$, which includes: reference, year of publication and country where the study was conducted, objective, study design, sample size, technologies used and main results.

\section{Evaluation of the included studies}

The methodological quality of the primary studies included in the sample was assessed using tools made available by the Joanna Briggs Institute $(\mathrm{JBI})^{(16)}$, also independently, by two reviewers (L.P.O. and L.G.V.). The methodological quality assessment tools made available by the JBI incorporate a process of critique or evaluation of research evidence. The goal is to assess the methodological quality of a study and determine the extent to which it addresses the possibility of bias in its design, conduct and analysis. All primary studies included in the review need to undergo rigorous evaluation by two reviewers and in a masked fashion. The results of this evaluation can then be used to inform the synthesis and interpretation of the study results. The critical appraisal tools were developed by JBI and collaborators and approved by the JBI Scientific Committee after extensive peer review ${ }^{(16)}$.

This evaluation was performed considering the appropriate tool for each type of design included. The third reviewer (D.R.F.) was called to solve the impasses of this evaluation in case of conflict between the first two reviewers.

The study was categorized as "high risk of bias" when the score of "yes" answers was below 49\% on the JBI tool; "moderate" when the score of "yes" answers reached 50\% to 69\%; and "low" when it reached a score of "yes" answers above $70 \%{ }^{(17)}$. Thus, it is clarified

Chart 1 - Search strategies performed in each database, Ribeirão Preto, São Paulo, Brazil, 2020

\begin{tabular}{|c|c|c|}
\hline Database & Search strategy & $\begin{array}{l}\text { Total of } \\
\text { identified } \\
\text { studies }\end{array}$ \\
\hline CINAHL & $\begin{array}{l}\text { ("surgical wound infection" OR "surgical wound infections" OR "surgical site infection" OR "surgical site infections" } \\
\text { OR "postoperative wound infection" } O R \text { "wound infection" } O R \text { "wound infection" } O R \text { "wound infections" } O R \\
\text { "surgical wound" } A N D \text { "incision care" } O R \text { "self care" OR "self care") }\end{array}$ & 150 studies \\
\hline EMBASE & $\begin{array}{l}\text { ("surgical wound infection" } O R \text { "surgical wound infections" } O R \text { "surgical site infection" OR "surgical site infections" } \\
\text { OR "postoperative wound infection" } O R \text { "wound infection" } O R \text { "wound infection" OR "wound infections" } O R \\
\text { "surgical wound" } A N D \text { "incision care" } O R \text { "self care" } O R \text { "self care") }\end{array}$ & 43 studies \\
\hline LILACS & $\begin{array}{l}\text { ("surgical wound infection" OR "infección de la herida quirúrgica" } O R \text { "infecção da ferida cirúrgica" OR "surgical site } \\
\text { infection" } O R \text { "infección del sitio quirúrgico" OR "infeçẫo do sítio cirúrgico" OR "postoperative wound infection" OR } \\
\text { "infección de la herida postoperatoria" OR "infecção pós-operatória da ferida" OR "wound infection" OR "infección } \\
\text { de heridas" OR "infecção dos ferimentos" OR "surgical wound" OR "herida quirúrgica" OR "ferida cirúrgica" AND } \\
\text { "incision care" OR cuidado de la incisión OR "cuidados de incisão" OR "self care" OR autocuidado) }\end{array}$ & 13 studies \\
\hline PubMed & $\begin{array}{l}\text { ("surgical wound infection"[MeSH Terms] OR "surgical wound infection" [All Fields] OR "surgical wound infections" } \\
\text { OR "surgical site infection" OR "surgical site infections" OR "postoperative wound infection" OR "wound } \\
\text { infection"[MeSH Terms] OR "wound infection" OR "wound infections" OR "surgical wound") AND ("incision care" OR } \\
\text { "self care"[MeSH Terms] OR "self care"[All Fields]) }\end{array}$ & 83 studies \\
\hline Scopus & $\begin{array}{l}\text { ("surgical wound infection" OR "surgical wound infections" } O R \text { "surgical site infection" OR "surgical site infections" } \\
\text { OR "postoperative wound infection" } O R \text { "wound infection" } O R \text { "wound infection" OR "wound infections" OR } \\
\text { "surgical wound" } A N D \text { "incision care" OR "self care" OR "self care") }\end{array}$ & 309 studies \\
\hline Web of Science & $\begin{array}{l}\text { ("surgical wound infection" OR "surgical wound infections" OR "surgical site infection" OR "surgical site infections" } \\
\text { OR "postoperative wound infection" } O R \text { "wound infection" } O R \text { "wound infection" OR "wound infections" OR } \\
\text { "surgical wound" } A N D \text { "incision care" OR "self care" OR "self care") }\end{array}$ & 26 studies \\
\hline
\end{tabular}


that the greater the number of "yes" answers to the items evaluated in the tool, the higher the methodological quality of the study.

\section{Analysis of the results}

The data was analyzed qualitatively, and the primary studies were summarized descriptively.

\section{RESULTS}

In the databases, 624 studies were identified, 169 of which were excluded for being duplicates in at least two databases, totaling 455 studies screened for reading by title and abstract. Of these, 393 were excluded after reading the titles and abstracts, totaling 62 studies for reading in full. After that, nine studies were selected to compose the review. Then, a manual search of the references was performed, but no new articles were identified, leaving nine primary studies in the final sample of this integrative review. The flowchart illustrating the selection of studies is shown in Figure 1.

Table 2 shows the narrative synthesis of the selected articles with the main characteristics and results of the studies included in this review. The primary studies were published between the years 2011 and 2019, with the majority being in the English language (8/9), all published in international journals. Of the total, six are characterized as being of cross-sectional design ${ }^{(18-23)}$, two randomized clinical trials ${ }^{(9,24)}$ and a case report ${ }^{(25)}$.

The main technologies identified were mobile applications, text and image messaging applications, and computer software with various functionalities, including sending and receiving messages, exchanging images, evaluations, and data storage capacity.

Regarding the methodological quality of the included primary studies, four were classified as low risk of bias and therefore have a higher methodological quality. Three studies presented moderate risk of bias, with moderate methodological quality. Finally, two studies were classified as "high risk of bias", with low methodological quality.
Identification of studies via databases and registers

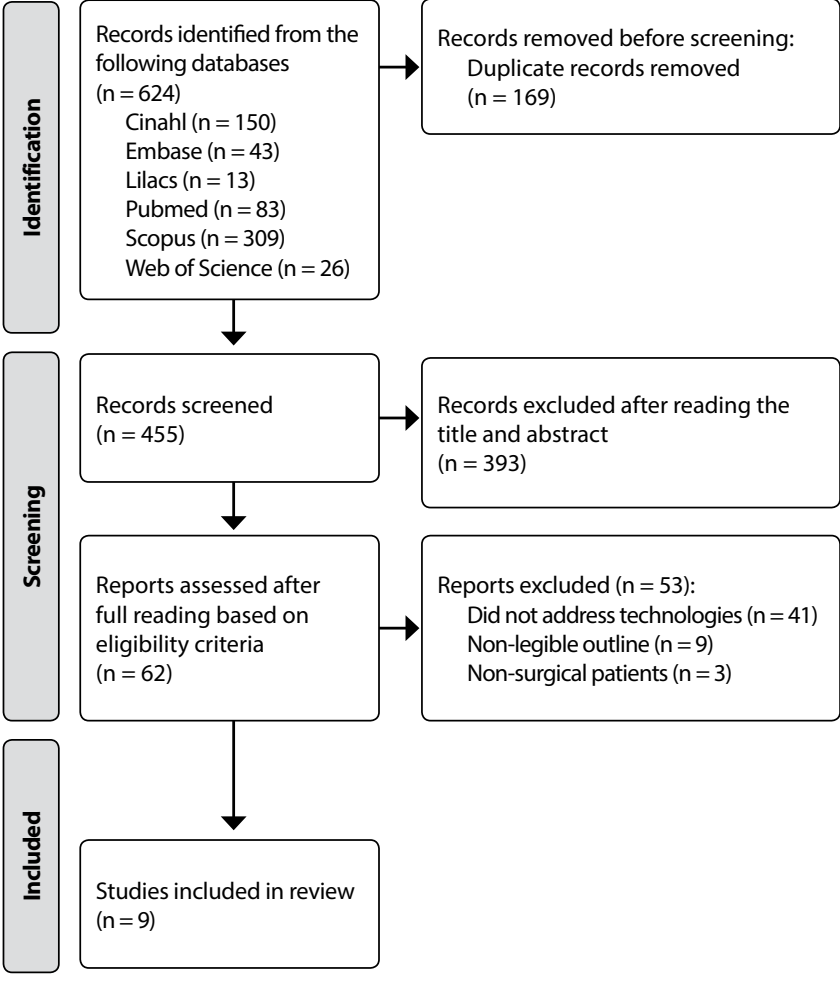

Figure 1 - Flowchart of the study selection process, according to adaptation of the Preferred Reporting Items for Systematic Reviews and Meta-Analyses

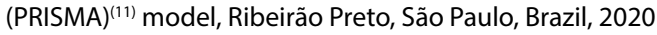

\section{DISCUSSION}

Nowadays, the use of health technologies is a growing innovation to improve health care. This study allowed us to synthesize information about the use of technology for self-care in surgical site infection surveillance. Thus, it was identified the use of mobile devices with access to camera, voice recorder, text messages, memory capacity,

Chart 2 - Synthesis chart of the studies included in the final sample of this integrative review, Ribeirão Preto, São Paulo, Brazil, 2020

\begin{tabular}{|c|c|c|c|c|c|c|}
\hline Reference & Objective & Study design & No. of patients & $\begin{array}{l}\text { Technological } \\
\text { interventions } \\
\text { used }\end{array}$ & Main results & $\begin{array}{c}\text { JBI* Bias } \\
\text { Risk }\end{array}$ \\
\hline $\begin{array}{l}\text { Abelson } \\
\text { et al., } \\
(2017)^{(18)} \\
\text { United } \\
\text { states of } \\
\text { America }\end{array}$ & $\begin{array}{l}\text { Verify the public's } \\
\text { willingness to engage } \\
\text { with mobile health } \\
\text { technology in the } \\
\text { post-operative } \\
\text { environment and } \\
\text { identify the specific } \\
\text { variables associated } \\
\text { with that willingness. }\end{array}$ & $\begin{array}{l}\text { Cross- } \\
\text { sectional } \\
\text { study }\end{array}$ & $\begin{array}{l}\text { A total of } 3,230 \\
\text { individuals were } \\
\text { contacted, of } \\
\text { whom 1,184 } \\
\text { were eligible. Of } \\
\text { those eligible, } 800 \\
\text { completed the } \\
\text { final survey. }\end{array}$ & $\begin{array}{l}\text { mHealth: } \\
\text { trackers, fill out } \\
\text { daily surveys, } \\
\text { send photos, } \\
\text { and share } \\
\text { updates with } \\
\text { selected family } \\
\text { and friends. }\end{array}$ & $\begin{array}{l}\text { Of the patients, } 80.6 \% \text { reported } \\
\text { greater willingness to wear a } \\
\text { tracker on their wrist; } 74.3 \% \text {, } \\
\text { fill out a daily survey; } 66.3 \% \text {, } \\
\text { send photos; and } 59.1 \% \text {, share } \\
\text { updates. Older age was not } \\
\text { associated with less willingness } \\
\text { to use mHealth. Hispanic } \\
\text { ethnicity was associated with } \\
\text { lower likelihood of using a } \\
\text { tracker on the wrist. Higher } \\
\text { education, internet trust, } \\
\text { and preexisting smartphone } \\
\text { use were all independently } \\
\text { associated with willingness to } \\
\text { engage with various mHealth } \\
\text { components. }\end{array}$ & Moderate \\
\hline
\end{tabular}


Chart 2

\begin{tabular}{|c|c|c|c|c|c|c|}
\hline Reference & Objective & Study design & No. of patients & $\begin{array}{l}\text { Technological } \\
\text { interventions } \\
\text { used }\end{array}$ & Main results & $\begin{array}{c}\text { JBI* Bias } \\
\text { Risk }\end{array}$ \\
\hline $\begin{array}{l}\text { Avery et al., } \\
(2019)^{(19)} \\
\text { England }\end{array}$ & $\begin{array}{l}\text { To describe the } \\
\text { development of } \\
\text { an ePRO system } \\
\text { integrated with a } \\
\text { hospital's electronic } \\
\text { health record to } \\
\text { improve the detection } \\
\text { of complications and } \\
\text { adverse effects after } \\
\text { discharge from cancer- } \\
\text { related surgery (major } \\
\text { abdominal surgery). }\end{array}$ & $\begin{array}{l}\text { Cross- } \\
\text { sectional } \\
\text { study }\end{array}$ & $\begin{array}{l}\text { Among the } \\
\text { patients, } 59 \\
\text { accessed the ePRO } \\
\text { system. }\end{array}$ & ePRO system & $\begin{array}{l}\text { Incorporating ePRO data into } \\
\text { clinical practice may bring } \\
\text { broader benefits to patients in } \\
\text { relation to surgical wound care } \\
\text { in cancer-related surgeries and } \\
\text { also to the healthcare system } \\
\text { by standardizing care practice, } \\
\text { streamlining and improving } \\
\text { clinical consultations, and } \\
\text { optimizing patient-centered care. }\end{array}$ & Moderate \\
\hline $\begin{array}{l}\text { Chang et } \\
\text { al., } \\
(2019)^{(9)} \\
\text { Taiwan }\end{array}$ & $\begin{array}{l}\text { Evaluate the } \\
\text { effectiveness of an } \\
\text { mHealth app on } \\
\text { patients' or caregivers' } \\
\text { and family members' } \\
\text { knowledge about } \\
\text { wound care, dressing } \\
\text { change skills, and } \\
\text { anxiety. }\end{array}$ & $\begin{array}{l}\text { Randomized } \\
\text { Clinical Trial }\end{array}$ & $\begin{array}{l}\text { A total of } 70 \\
\text { patients (or } \\
\text { family members) } \\
\text { were contacted } \\
\text { at a } 1,500 \text {-bed } \\
\text { university } \\
\text { hospital. They } \\
\text { were randomized } \\
\text { into an } \\
\text { experimental ( } \mathrm{n} \\
=35 \text { ) or a control } \\
\text { group ( } \mathrm{n}=35 \text { ). }\end{array}$ & $\begin{array}{l}\text { mHealth } \\
\text { developed on } \\
\text { the Android } \\
\text { platform }\end{array}$ & $\begin{array}{l}\text { Participants in both groups } \\
\text { (intervention and control) } \\
\text { showed significant improvement } \\
\text { in wound care between pre- } \\
\text { test T1 and post-tests T2 and } \\
\text { T3, but especially between T1 } \\
\text { and T3. They also significantly } \\
\text { improved their levels of wound } \\
\text { care skills, being higher for the } \\
\text { experimental group than for the } \\
\text { control group. With regard to } \\
\text { wound care anxiety, there was a } \\
\text { greater decrease in anxiety in the } \\
\text { experimental group than in the } \\
\text { control group. }\end{array}$ & Low \\
\hline $\begin{array}{l}\text { Chen et al., } \\
(2020)^{(20)} \\
\text { Taiwan }\end{array}$ & $\begin{array}{l}\text { Propose a surgical } \\
\text { wound assessment } \\
\text { system for self-care. }\end{array}$ & $\begin{array}{l}\text { Cross- } \\
\text { sectional } \\
\text { study }\end{array}$ & 46 patients & $\begin{array}{l}\text { Superpixel (high } \\
\text { resolution) } \\
\text { image capture } \\
\text { tool) }\end{array}$ & $\begin{array}{l}\text { The implementation of this } \\
\text { superpixel-cropped imaging } \\
\text { tool has enabled surgical wound } \\
\text { assessment to be performed } \\
\text { as reliably ( } 90 \% \text { accuracy) as } \\
\text { that performed by medical } \\
\text { professionals. }\end{array}$ & High \\
\hline $\begin{array}{l}\text { Holt, Flint, } \\
\text { Bowers, } \\
(2011)^{(25)} \\
\text { United } \\
\text { States of } \\
\text { America }\end{array}$ & $\begin{array}{l}\text { To demonstrate } \\
\text { whether using } \\
\text { audiovisual } \\
\text { technology to support } \\
\text { a patient through } \\
\text { discharge education } \\
\text { can promote } \\
\text { adherence to self-care } \\
\text { instructions, increase } \\
\text { patient autonomy, and } \\
\text { reduce poor quality } \\
\text { outcomes. }\end{array}$ & Case report & One patient & $\begin{array}{l}\text { Camera and } \\
\text { voice recording } \\
\text { from the } \\
\text { patient's cell } \\
\text { phone }\end{array}$ & $\begin{array}{l}\text { The intervention employed } \\
\text { represents an innovative way } \\
\text { to use the existing cell phone } \\
\text { technology to provide more } \\
\text { effective, patient-centered } \\
\text { discharge education, resulting in } \\
\text { patient compliance with all the } \\
\text { processes required for dressing } \\
\text { changes, patient satisfaction } \\
\text { and autonomy in the self-care } \\
\text { process, no infection or other } \\
\text { morbidities, and no need for } \\
\text { readmission. }\end{array}$ & Low \\
\hline $\begin{array}{l}\text { Sanger et } \\
\text { al., } \\
(2014)^{(21)} \\
\text { United } \\
\text { States of } \\
\text { America }\end{array}$ & $\begin{array}{l}\text { Exploring the patient } \\
\text { experience of opening } \\
\text { an mHealth wound } \\
\text { monitoring application } \\
\text { as a solution for SSI. }\end{array}$ & $\begin{array}{l}\text { Cross- } \\
\text { sectional } \\
\text { study }\end{array}$ & $\begin{array}{l}\text { Seventeen } \\
\text { eligible patients } \\
\text { were identified. } \\
\text { Of these, } 13 \\
\text { participated and } \\
4 \text { were willing } \\
\text { to participate } \\
\text { but faced time } \\
\text { constraints or had } \\
\text { psychiatric illness. }\end{array}$ & mPOWEr & $\begin{array}{l}\text { Three main themes emerged } \\
\text { during the interviews regarding } \\
\text { patients' self-care for post- } \\
\text { discharge wound complications, } \\
\text { which were knowledge for } \\
\text { self-care and self-monitoring, } \\
\text { efficacy for self-care and } \\
\text { wound monitoring at home, } \\
\text { and communication with } \\
\text { providers. While considering the } \\
\text { acceptability, perceived benefits, } \\
\text { and potential limitations of an } \\
\text { mHealth solution, participants } \\
\text { perceived that this solution } \\
\text { can address post-discharge } \\
\text { challenges by enabling more } \\
\text { frequent, comprehensive follow- } \\
\text { up, leading to less anxiety and } \\
\text { fewer unnecessary visits to the } \\
\text { health care facility. }\end{array}$ & Low \\
\hline
\end{tabular}




\begin{tabular}{|c|c|c|c|c|c|c|}
\hline Reference & Objective & Study design & No. of patients & $\begin{array}{l}\text { Technological } \\
\text { interventions } \\
\text { used }\end{array}$ & Main results & $\begin{array}{c}\text { JBI* Bias } \\
\text { Risk }\end{array}$ \\
\hline $\begin{array}{l}\text { Tofte et al., } \\
(2018)^{(22)} \\
\text { United } \\
\text { States of } \\
\text { America }\end{array}$ & $\begin{array}{l}\text { To explore the safety, } \\
\text { efficacy, and patient } \\
\text { convenience of using } \\
\text { a new smartphone } \\
\text { app for postoperative } \\
\text { care after carpal tunnel } \\
\text { release. }\end{array}$ & $\begin{array}{l}\text { Cross- } \\
\text { sectional } \\
\text { study }\end{array}$ & 16 patients & $\begin{array}{l}\text { Mobile } \\
\text { Application }\end{array}$ & $\begin{array}{l}\text { All patients successfully } \\
\text { completed the removal of the } \\
\text { dressing. Overall, ten of } 16 \\
\text { patients ( } 63 \%) \text { were able to } \\
\text { successfully remove their sutures. } \\
\text { Fifteen patients ( } 94 \%) \text { captured } \\
\text { wound photos, although one } \\
\text { photo was deemed too blurry for } \\
\text { analysis. For the } 14 \text { patients who } \\
\text { had a clinically adequate wound } \\
\text { photo and clinical documentation } \\
\text { of symptoms available, the } \\
\text { authors classified the wound } \\
\text { as'uncomplicated','macerated', } \\
\text { 'open' or 'infected'. With the } \\
\text { exception of a single patient with } \\
\text { mild wound maceration, no other } \\
\text { significant wound complications } \\
\text { were identified at the } 10-\text { to } \\
14-\text { day postoperative personal } \\
\text { visit or during the review of the } \\
\text { wound photographs. }\end{array}$ & Moderate \\
\hline $\begin{array}{l}\text { Yahanda } \\
\text { et al., } \\
(2019)^{(24)} \\
\text { United } \\
\text { States of } \\
\text { America }\end{array}$ & $\begin{array}{l}\text { Evaluate the use and } \\
\text { patient satisfaction } \\
\text { of text and voice } \\
\text { telemonitoring } \\
\text { interventions to } \\
\text { prevent and identify } \\
\text { SSI after joint } \\
\text { replacement. }\end{array}$ & $\begin{array}{l}\text { Pilot clinical } \\
\text { trial }\end{array}$ & $\begin{array}{l}1,392 \text { patients } \\
\text { were enrolled in } \\
\text { EpxDecol and } \\
1,753 \text { patients in } \\
\text { EpxWound. }\end{array}$ & $\begin{array}{l}\text { EpxDecol and } \\
\text { EpxWound } \\
\text { (text and voice } \\
\text { messages) }\end{array}$ & $\begin{array}{l}\text { The proportion of patients who } \\
\text { responded daily on ExpDecol was } \\
91 \% \text { and of those who responded } \\
\text { on ExpWound was } 77.7 \% \text {. The } \\
\text { response percentage decreased } \\
\text { by } 5 \% \text { during each intervention. } \\
\text { In final analysis, } 88.4 \% \text { of } \\
\text { EpxDecol patients and } 67.8 \% \text { of } \\
\text { ExpWound patients responded } \\
\text { to } 80 \% \text { of all messages. For a } \\
\text { survey of satisfaction with the } \\
\text { interventions, a cohort of } 1,246 \\
\text { post-intervention patients was } \\
\text { used: the average response of } \\
\text { how patients rated the care was } \\
9 / 9, \text { that is, } 8 / 9 \text { for enhanced } \\
\text { communication and } 5 / 9 \text { for the } \\
\text { number of messages received. }\end{array}$ & Alto \\
\hline $\begin{array}{l}\text { Anthony } \\
\text { et al., } \\
(2018)^{(23)} \\
\text { United } \\
\text { States of } \\
\text { America }\end{array}$ & $\begin{array}{l}\text { To describe a method } \\
\text { of communicating } \\
\text { with patients } \\
\text { postoperatively } \\
\text { outside of the } \\
\text { traditional healthcare } \\
\text { setting, using an } \\
\text { automated software } \\
\text { and cell phone } \\
\text { messaging platform; } \\
\text { and to evaluate } \\
\text { the first week } \\
\text { postoperatively. }\end{array}$ & $\begin{array}{l}\text { Cross- } \\
\text { sectional } \\
\text { study }\end{array}$ & 47 patients & $\begin{array}{l}\text { Automated } \\
\text { software and } \\
\text { cell phone } \\
\text { messaging } \\
\text { platform }\end{array}$ & $\begin{array}{l}\text { The trend of pain decreased daily } \\
\text { in the first postoperative week, } \\
\text { with the highest levels of pain } \\
\text { reported in the first } 48 \text { hours } \\
\text { after surgery. Patients reported } \\
\text { an average use of } 15.9 \text { tablets of } \\
\text { prescribed opioid analgesic. } \\
\text { The use of a cell phone } \\
\text { messaging software robot allows } \\
\text { for effective data collection on } \\
\text { postoperative pain and analgesic } \\
\text { use. }\end{array}$ & Low \\
\hline
\end{tabular}

*JBI - Joanna Briggs Institute.

software with ability to download applications and internet access, as well as trackers and a messaging software robot $^{(18,23)}$.

Mobile apps, the main technologies identified in the literature, can contribute to individuals in managing their own health and well-being, as well as promoting a healthier lifestyle. Data from the Food and Drug Administration (FDA) in the United States showed that in 2018, about 2 billion individuals with smartphones and tablets were using some type of health-related app ${ }^{(26)}$.

The results of this review showed that patients were willing to use mobile technologies and mHealth apps, as seen in the studies by Abelson et al. ${ }^{(18)}$ and Yahanda et al. ${ }^{(24)}$. In the latter, this willingness was evidenced by the proportion of patients who responded daily to the EpxDecol and EpxWound apps, $91 \%$ and $77.7 \%$, respectively. The willingness to use technology was considered a concern, especially among older populations, since they are more likely to present difficulties arising from lack of familiarity with technology, fear and insecurity in handling electronic devices, visual, motor, memory and attention difficulties. In contrast, guided by motivation and commitment to learn more about their own health, they showed great interest in using 
the Internet and electronic devices ${ }^{(27)}$. According to the results of this review, they are willing to use these mechanisms thinking about their own well-being and postoperative improvement.

Considering the important role that technologies can play in patient education, selfmanagement of health, and remote monitoring by health care professionals, their use has received increasing prominence and influence ${ }^{(6)}$. This is supported by the study of Chang et al. ${ }^{(9)}$, which evaluated the efficacy of an mHealth app in increasing the knowledge of patients or their caregivers and family members about wound care while using the app: a significant improvement in surgical wound dressing change skills was identified, as well as a decrease in anxiety and negative feelings related to surgical wound care in the experimental group. Similarly, the study by Tofte et al. ${ }^{(22)}$ explored the safety, efficacy, and convenience of using a new smartphone application for postoperative care and demonstrated that all patients involved were able to successfully complete dressing removal, and some were even able to remove their sutures using the information on the application.

In addition, a study with breast cancer patients showed that, like the study by Chen et al. ${ }^{(20)}$, who proposed a surgical wound assessment system using a superpixel (high-resolution) image capture tool, the implementation of technologies has allowed an assessment as reliable as the face-to-face evaluation. This indicates that involving health care professionals in remote monitoring through applications may be a cheaper and more effective alternative for improving health outcomes management ${ }^{(28)}$. The study by Sanger et al. ${ }^{(21)}$ identified that patients considered the application of mHealth positive due to more frequent, close and complete follow-up, with fewer visits to the health service; and ratified another study, in which it was pointed out that followup through apps can help reduce unplanned visits and hospital readmissions, with a consequent reduction in anxiety and fear among patients ${ }^{(29)}$.

Health support based on web technologies and mobile apps, with the involvement of health professionals, is of paramount importance to ensure quality communication between patients and health care team, empowering patients to increase adherence to self-care, quality of treatment, level of confidence, and promotion of emotional well-being ${ }^{(30-31)}$. This is also demonstrated by the study of Holt, Flint and Bowers ${ }^{(25)}$, in which the intervention consisted of using audiovisual resources (camera and voice recorder) as an innovative way to provide discharge education more efficiently and centered on the patient's demands, ensuring better adherence to treatment and greater patient autonomy in self-care.
In this sense, mobile health technologies are increasingly gaining space in clinical care and can provide significant informational potential. However, more research is needed to confirm the benefits for patients and health professionals, as they are often introduced into the health care setting without quality scientific evidence.

\section{Study limitations}

The use of technologies for surveillance and self-care of the surgical wound depends on factors other than the technologies themselves. Education level and age of patients can be determinants for the choice and proper functioning of the technology to be used.

Moreover, the development, the confirmation of the potential benefits for patients and health professionals, and the implementation of these technologies in health care require time and often high costs. Therefore, they need to be carefully evaluated through quality and efficacy research.

Because this review presented a relatively low number of included studies, it cannot be said that all existing and applied technologies for this purpose were addressed here, being a limitation of this study.

\section{Contributions to the field of Nursing, Health or Public Policy}

The use of technology through smartphones and mobile applications by the general population can positively assist in the provision of safe health care, because it allows greater proximity to the health professional, as well as easy and quick access to questions and resolution of doubts. This review shows that the use of apps in health care is a growing reality, with effective and satisfactory results for patients who have used them. These results may motivate professionals to create other apps for health care in different areas other than postoperative surveillance.

\section{CONCLUSIONS}

The technologies identified for self-care in the surveillance of surgical wound infection with primary closure were the creation and use of mHealth and the use of health apps on mobile devices. Such technologies are effective in surveillance of surgical wound infection, as they allow proximity to the healthcare team. In addition, they encourage a greater number of surgical wound assessments, which intensifies self-care actions and decreases patient anxiety. The technology is also a monitored and recorded form of patient care, meeting one of the main axes of infection surveillance.

\section{REFERENCES}

1. Carvalho RLR, Campos CC, Franco LMC, Rocha AM, Ercole FF. Incidência e fatores de risco para infecção de sítio cirúrgico em cirurgias gerais. Rev Latino-Am Enfermagem. 2017;25:e2848. https://doi.org/10.1590/1518-8345.1502.2848

2. Sociedade Beneficente Israelita Brasileira Albert Einstein. Manual de prevenção de infecção de sítio cirúrgico [Internet]. 2014 [cited 2021 Feb 25]. Available from: https://medicalsuite.einstein.br/pratica-medica/guias-e-protocolos/Documents/manual_infeccao_zero_compacto.pdf

3. Agência Nacional de Vigilância Sanitária (BR). Critérios diagnósticos de infecção relacionada à assistência à saúde [Internet]. Brasília, DF: Anvisa; 2017 [cited 2021 Feb 25]. (Série Segurança do paciente e qualidade em serviços de saúde). Available from: http://bvsms.saude.gov. br/bvs/publicacoes/criterios_diagnosticos_infeccoes_assistencia_saude.pdf 
4. Ministério da Saúde (BR). Documento de referência para o programa nacional de segurança do paciente [Internet]. 2014 [cited 2020 Sep 07]. 42 p. Available from: http://bvsms.saude.gov.br/bvs/publicacoes/documento_referencia_programa_nacional_seguranca.pdf

5. Damion M, Moreira MC. Percepção do paciente sobre sua autonomia na unidade de terapia intensiva. Contextos Clin. 2018;11(3):386-96. https://doi.org/10.4013/ctc.2018.113.09

6. Mosa ASM, Yoo I, Sheets L. A systematic review of healthcare applications for smartphones. BMC Med Inform Decis Mak. 2012;12:67. https:// doi.org/10.1186/1472-6947-12-67

7. Cruz FOAM, Vilela RA, Ferreira EB, Melo NS, Reis PED. Evidence on the use of mobile apps during the treatment of breast cancer: systematic review. JMIR Mhealth Uhealth. 2019;7(8):e13245. https://doi.org/10.2196/13245

8. Singh K, Drouin K, Newmark LP, Filkins M, Silvers E, Bain PA, et al. Patient-facing mobile apps to treat high-need, high-cost populations: a scoping review. JMIR Mhealth Uhealth. 2016;4(4):e136. https://doi.org/10.2196/mhealth.6445

9. Chang H-Y, Hou Y-P, Yeh F-H, Lee S-S. The impact of an mHealth app on knowledge, skills and anxiety about dressing changes: a randomized controlled trial. J Adv Nurs. 2020;76(4):1046-56. https://doi.org/10.1111/jan.14287

10. Mendes KDS, Silveira RCCP, Galvão CM. Revisão integrativa: método de pesquisa para a incorporação de evidências na saúde e na enfermagem. Texto Contexto Enferm. 2008;17(4):58-64. https://doi.org/10.1590/S0104-07072008000400018

11. Page MJ, McKenzie JE, Bossuyt PM, Boutron I, Hoffmann TC, Mulrow CD, et al. The PRISMA 2020 statement: an updated guideline for reporting systematic reviews. BMJ 2021;372:n71. https://doi.org/10.1136/bmj.n71

12. Pereira MG, Galvão TF. Etapas de busca e seleção de artigos em revisões sistemáticas da literatura. Epidemiol Serv Saude. 2014;23(2):369-71. https://doi.org/10.5123/S1679-49742014000200019

13. Mendes KDS, Silveira RCCP, Galvão CM. Use of the bibliographic reference manager in the selection of primary studies in integrative reviews. Texto Contexto Enferm. 2019;28:e2017020417. https://doi.org/10.1590/1980-265x-tce-2017-0204

14. Ouzzani M, Hammady H, Fedorowicz Z, Elmagarmid A. Rayyan: a web and mobile app for systematic reviews. Syst Rev. 2016;5(1):210. https://doi.org/10.1186/s13643-016-0384-4

15. Silveira RCCP, Reis PED, Ferreira EB, Braga FTMM, Galvão CM, Clark AM. Dressings for the central venous catheter to prevent infection in patients undergoing hematopoietic stem cell transplantation: a systematic review and meta-analysis. Support Care Cancer. 2020;28(2):42538. https://doi.org/10.1007/s00520-019-05065-9

16. Aromataris $\mathrm{E}$, Munn Z, editors. JBI manual for evidence synthesis: version 2.0 [Internet]. Adelaide (AU): JBI; 2020 [cited 2021 Feb 25 ]. Available from: https://jbi-global-wiki.refined.site/space/MANUAL

17. Polmann H, Melo G, Réus JC, Domingos FL, Souza BDM, Padilha AC, et al. Prevalence of dentofacial injuries among combat sports practitioners: a systematic review and meta-analysis. Dent Traumatol. 2020;36(2):124-40. https://doi.org/10.1111/edt.12508

18. Abelson JS, Symer M, Peters A, Charlson M, Yeo H. Mobile heath apps and recovery after surgery: what are patients willing to do?. Am J Surg. 2017;214(4):616-22. https://doi.org/10.1016/j.amjsurg.2017.06.009

19. Avery KNL, Richards HS, Portal A, Reed T, Harding R, Carter R, et al. Developing a real-time electronic symptom monitoring system for patients after discharge following cancer-related surgery. BMC Cancer. 2019;19(1):463. https://doi.org/10.1186/s12885-019-5657-6

20. Chen Y-W, Hsu J-T, Hung C-C, Wu J-M, Lai F, Kuo S-Y. Surgical wounds assessment system for self-care. IEEE Trans Syst Man Cybern Syst. 2020;50(2):5076-91. https://doi.org/10.1109/TSMC.2018.2856405

21. Sanger PC, Hartzler A, Han SM, Armstrong CAL, Stewart MR, Lordon RJ, et al. Patient perspectives on post-discharge surgical site infections: towards a patient-centered mobile health solution. PLoS One. 2014;9(12):e114016. https://doi.org/10.1371/journal.pone.0114016

22. Tofte JN, Anthony CA, Polgreen PM, Buckwalter JA, Caldwell LS, Fowler TP, et al. Postoperative care via smartphone following carpal tunnel release. J Telemed Telecare. 2020;26(4):223-31. https://doi.org/10.1177/1357633X18807606

23. Anthony CA, Lawler EA, Ward CM, Lin IC, Shah AS. Use of an automated mobile phone messaging robot in postoperative patient monitoring. Telemed J E Health. 2018;24(1):61-6. https://doi.org/10.1089/tmj.2017.0055

24. Yahanda AT, Marino NE, Barron J, Concepcion A, St John T, Lu K, et al. Patient engagement and cost savings achieved by automated telemonitoring systems designed to prevent and identify surgical site infections after joint replacement. Telemed J E Health. 2019;25(2):14351. https://doi.org/10.1089/tmj.2017.0325

25. Holt JE, Flint EP, Bowers MT. Got the picture?: using mobile phone technology to reinforce discharge instructions. Am J Nurs. 2011;111(8):4751. https://doi.org/10/1097/01.NAJ.0000403363.66929.41

26. U.S. Food and Drug Administration. Device software functions including mobile medical applications [Internet]. [place unknown]: FDA; 2019 [cited 2021 Jul 14]. Available from: https://www.fda.gov/medical-devices/digital-health/mobile-medical-applications

27. Bernardes MS, Valdrighi JC, Pereira J, Domingos LB, Santana CS. Tecnologia móvel para a gestão da saúde de idosos: revisão da literatura [Internet]. J Health Inform. 2016 [cited 2021 Jul 14];8(Suppl 1):1081-8. Available from: https://docs.bvsalud.org/biblioref/2018/07/906823/ anais_cbis_2016_artigos_completos-1081-1088.pdf

28. Graetz I, McKillop CN, Stepanski E, Vidal GA, Anderson JN, Schwartzberg LS. Use of a web-based app to improve breast cancer symptom management and adherence for aromatase inhibitors: a randomized controlled feasibility trial. J Cancer Surviv. 2018;12(4):431-40. https:// doi.org/10.1007/s11764-018-0682-z 
29. Hwang $\mathrm{H}$. Electronic wound monitoring after ambulatory breast cancer surgery: improving patient care and satisfaction using a smart phone app [Internet]. BCMJ. 2016 [cited 2021 Jul 14];58(8):448-53. Available from: https://www.bcmj.org/articles/ electronic-wound-monitoring-after-ambulatory-breast-cancer-surgery-improving-patient-care

30. Zhu J, Ebert L, Guo D, Yang S, Han Q, Chan SW-C. Mobile breast cancer e-support program for Chinese women with breast cancer undergoing chemotherapy (part 1): qualitative study of women's perceptions. JMIR Mhealth Uhealth. 2018;6(4):e85. https://doi. org/10.2196/mhealth.9311

31. Ekstedt M, Børøsund E, Svenningsen IK, Ruland CM. Reducing errors through a web-based self-management support system. Stud Health Technol Inform. 2014;201:328-34. https://doi.org/10.3233/978-1-61499-415-2-328 